\title{
Student Potential for Self-assessment in a Clinical Dentistry Practical Training Course on Communication Skills
}

\author{
Asami Iguchi ${ }^{1} \cdot$ Yuh Hasegawa $^{2}$ (D) Kazuyuki Fujii ${ }^{1}$ \\ Published online: 20 August 2020 \\ (C) The Author(s) 2020
}

\begin{abstract}
This study aimed to investigate student potential for self-assessment in a clinical dentistry practical training course focused on communication skills. Participants were 124 fourth-year students (70 males, 54 females; all Japanese) in 2017 and 2018 at the Nippon Dental University, School of Life Dentistry at Niigata. Participating students belonged to different cohorts in 2017 and 2018. Participants were asked to complete a self-evaluation sheet at the end of each unit of the course. Their self-evaluation scores and the faculty evaluation scores for each student for Units 1-1, 1-2, and 1-3 were statistically analyzed. The results showed that females tended to rate themselves significantly higher than males. Furthermore, there were significant differences in evaluation scores between students and faculty for nine of 11 evaluation items for male students and 10 of 11 items for female students in Unit 1-3. Faculty expectations increased from Unit 1-1 to Unit 1-3, although students were satisfied with their performance and had a sense of achievement. However, students' actual performance was below faculty expectations, suggesting faculty evaluations were stricter than students' self-evaluation. Self-assessment may enhance students' ability for self-directed learning and may also inform how faculty can effectively educate dental students. Dental educators should support students to increase their levels of self-efficacy, which will enhance their self-evaluation skills.
\end{abstract}

Keywords Dental students $\cdot$ Self-assessment $\cdot$ Assessment $\cdot$ Communication skills $\cdot$ Dental education

\section{Introduction}

Many studies around the world have addressed students' selfevaluation in pharmaceutical education [1-8], medical education [9-14], and dental education [15-21]. Dentistry is a selfanalytic profession, and dentists must be able to properly evaluate every procedure performed. Self-assessment is a critical skill that dentists must have to be competent oral healthcare providers [17]. Hadid [10] defined self-assessment based on a report by McMillan and Hearn [22] as being a process by which students monitor and evaluate the quality of their thinking and behavior when learning, and identify strategies that improve their understanding and skills. Dental students'

Yuh Hasegawa

haseyu@ngt.ndu.ac.jp

1 School of Life Dentistry at Niigata, The Nippon Dental University, 1-8, Hamaura-cho, Chuo-ku, Niigata 951-8580, Japan

2 The Nippon Dental University College at Niigata, 1-8, Hamaura-cho, Chuo-ku, Niigata 951-8580, Japan ability to self-evaluate their work may be an effective learning tool as it enhances their performance in each step [16]. Accurate self-assessment reflects an ability to accurately assess one's strengths and weaknesses and is an underlying feature of self-directed lifelong learning. However, the role of students' self-evaluation remains controversial despite some attempts to clarify this aspect through comparisons with peerreview and faculty evaluations $[1,3,7,19]$. Especially, the sex-based difference in self-assessment scores is still a controversial issue. Several studies revealed that students' sex did not affect self-evaluation [10, 23-25]. However, other studies have found that gender does affect self-evaluation. Vivekananda-Schmidt et al. [26] and some other researchers advocated in their article that female students tend to underestimate themselves compared with male students on self-evaluation [12, 27]. Wiener et al. [15] and other studies $[14,28]$ reported that female students' self-evaluations were higher than those of male students.

Dental schools in Japan adopt a 6-year course program comprising 12 semesters. Students enter dental school immediately after graduation from high school. A typical example of the dental school curriculum is as follows. The first year 
involves general sciences, with preclinical training in the second to fourth years, clinical practicum at the university clinic in the fifth year, and classroom lectures to prepare for the National Board examination in the sixth year. In the second semester of the fourth year at the Nippon Dental University School of Dentistry at Niigata, students complete a "communication skills in clinical dentistry" practical training course. This course consists of three parts: medical interviews (five units), cooperation among healthcare professionals (1 unit), and treatment plan report ( 1 unit). All students spend $3 \mathrm{~h}$ per week on each unit in the course.

This study aimed to investigate students' potential for selfevaluation in a clinical dentistry practical training course on communication skills in a Japanese dental school. To our knowledge, no studies have examined Japanese dental students during a clinical dentistry practical training course on communication skills. Specifically, we analyzed possible differences between male and female students. The null hypotheses were as follows: there was no difference between male and female students' self-evaluation scores and there was no difference between students' self-evaluation and faculty evaluation.

\section{Materials and Methods}

Approval for this study was obtained from the Research Ethics Committee of The Nippon Dental University, School of Life Dentistry at Niigata (Approval No. ECNG-E-3). Participants were fourth-year students in 2017 and 2018 at the Nippon Dental University, School of Life Dentistry at Niigata. Students in 2017 and 2018 were different cohorts, and a total number of students were 142 ( 84 males, 58 females; all Japanese). Students who stayed in the same class for another year (14 males, four females; all Japanese) were excluded. Finally, the 124 students (70 males, 54 females; all Japanese) who participated in this study signaled their agreement to participate by completing a consent form.

Table 1 shows the course syllabus for the communication skills in clinical dentistry practical training course. This three-unit course is held once per week, and students spend $3 \mathrm{~h}$ on each unit. Participating students were asked to complete a self-evaluation sheet at the end of each unit, which was at weekly intervals.

On the first day of communication skills in clinical dentistry practical training course, students were informed about the evaluation items and their criterion using slides through a PowerPoint presentation and printed matter. The evaluation items and their criterion are shown in Table 2. The selfevaluation sheet includes a 4-point Likert scale $(1=$ poor, 2 = fair, $3=$ good, $4=$ excellent), and participating students were asked to complete the self-evaluation for each evaluation items on the 4-point Likert scale [6, 17]. Faculties evaluate
Table 1 Communication skills in clinical dentistry practical training course syllabus

\begin{tabular}{|c|c|c|c|}
\hline Unit & Theme & Content & Method \\
\hline $1-1$ & $\begin{array}{l}\text { Introduction to } \\
\text { medical } \\
\text { interviews }\end{array}$ & $\begin{array}{l}\text { Medical interviews for } \\
\text { narrative-based medicine }\end{array}$ & $\begin{array}{l}\text { Role play and } \\
\text { group } \\
\text { discussion }\end{array}$ \\
\hline $1-2$ & $\begin{array}{l}\text { Medical } \\
\text { interview } \\
\text { (chronic } \\
\text { symptoms) }\end{array}$ & $\begin{array}{l}\text { Interviewing a person with } \\
\text { chronic symptoms to } \\
\text { obtain their medical } \\
\text { history }\end{array}$ & $\begin{array}{l}\text { Role play and } \\
\text { group } \\
\text { discussion }\end{array}$ \\
\hline $1-3$ & $\begin{array}{l}\text { Medical } \\
\text { interview } \\
\text { (acute } \\
\text { symptoms) }\end{array}$ & $\begin{array}{l}\text { Interviewing a person with } \\
\text { acute symptoms to } \\
\text { obtain their medical } \\
\text { history }\end{array}$ & $\begin{array}{l}\text { Role play and } \\
\text { group } \\
\text { discussion }\end{array}$ \\
\hline 2 & $\begin{array}{l}\text { Cooperation } \\
\text { among } \\
\text { healthcare } \\
\text { professionals }\end{array}$ & $\begin{array}{l}\text { Producing documents } \\
\text { (referral forms, } \\
\text { prescriptions, and } \\
\text { technical material order } \\
\text { forms) }\end{array}$ & $\begin{array}{l}\text { Simulation and } \\
\text { group } \\
\text { discussion }\end{array}$ \\
\hline 3 & $\begin{array}{l}\text { Treatment plan } \\
\text { report }\end{array}$ & $\begin{array}{l}\text { Reporting a treatment plan } \\
\text { for a prosthesis to a } \\
\text { patient and obtaining } \\
\text { informed consent }\end{array}$ & $\begin{array}{l}\text { Role play and } \\
\text { group } \\
\text { discussion }\end{array}$ \\
\hline $1-4$ & $\begin{array}{l}\text { Medical } \\
\quad \text { interview } \\
\text { (examination) }\end{array}$ & $\begin{array}{l}\text { Interviewing a simulated } \\
\text { patient to obtain their } \\
\text { medical history }\end{array}$ & $\begin{array}{l}\text { Practical } \\
\quad \text { examination }\end{array}$ \\
\hline $1-5$ & $\begin{array}{l}\text { General overview } \\
\text { of medical } \\
\text { interviews }\end{array}$ & $\begin{array}{l}\text { Looking back over the } \\
\text { examples of typical } \\
\text { symptoms for a medical } \\
\text { interview }\end{array}$ & $\begin{array}{l}\text { Role play, } \\
\text { simulation, } \\
\text { and group } \\
\text { discussion }\end{array}$ \\
\hline
\end{tabular}

students on the 4-point Likert scale with the same criterion of evaluation items. Through the "communication skills in clinical dentistry practical training course," the same evaluation sheet and items were used for evaluation. At the end of each unit, faculty feedback to the students was made including selfevaluation scores. At the beginning of the next unit, face to face individual feedback was made, if there was a two-point difference in the score between student self-evaluation and faculty evaluation on the Likert scale.

Participating students were evaluated by six tutors (three males, three females). The same six tutors evaluated students in both 2017 and 2018. Regarding the students' evaluation, each tutor was responsible for evaluating 20 to 22 students. Some of the evaluation items are subjective and the tutors evaluate students with the viewpoints of clinical dentists. The tutors have over 10 years of clinical experience as the clinical dentists and they were well trained in obtaining concordance of student evaluation. The six tutors confirmed the evaluation criterion prior to the start of the "communication skills in clinical dentistry practical course" in each year, with evaluating the simulated student acted by the other faculty member. They have over 10 years of experience of student evaluation in the "communication skills in clinical dentistry practical course." 


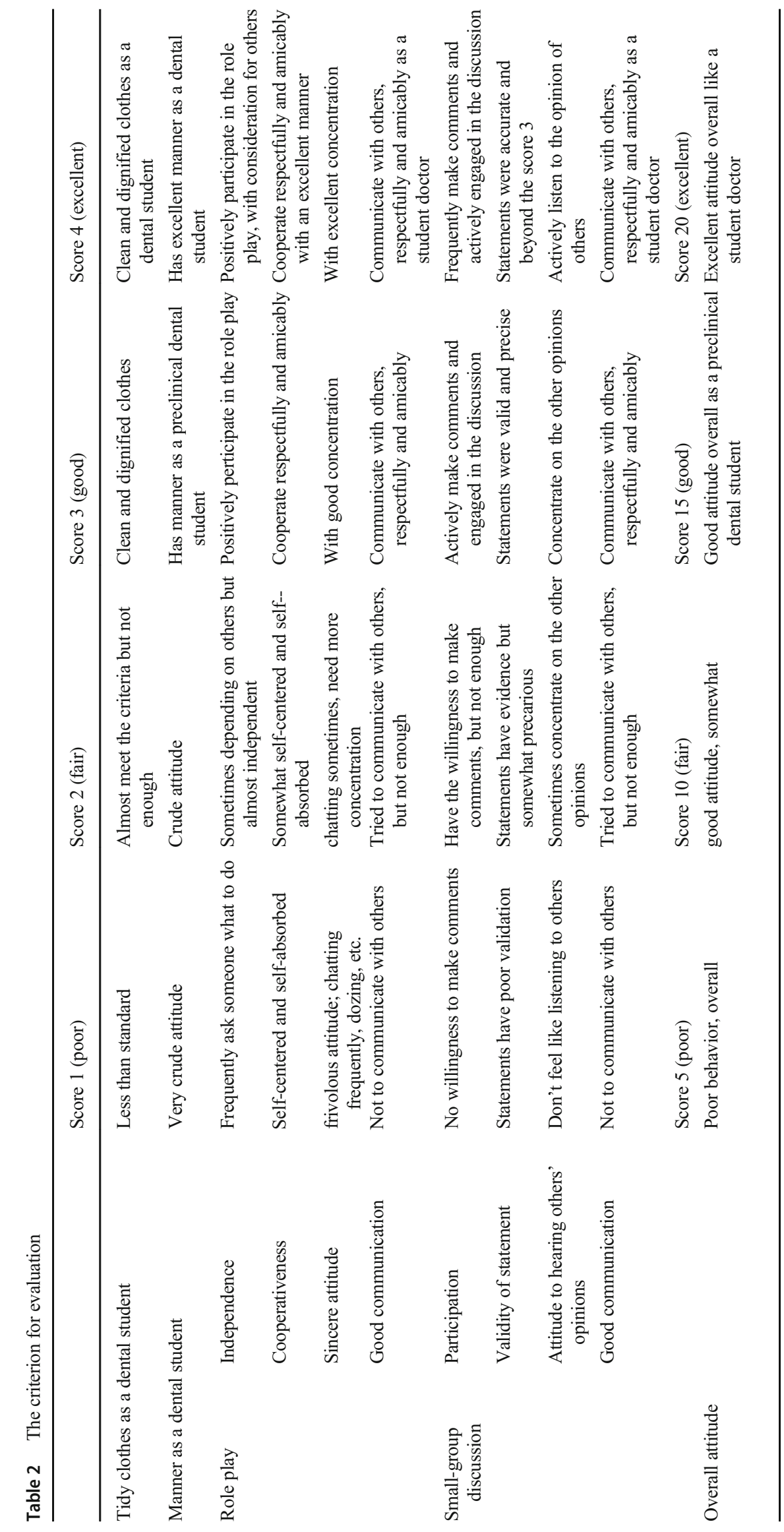


Self-evaluation scores and faculty evaluation scores for each student for Units 1-1, 1-2, and 1-3 were statistically analyzed. First, mean value comparisons for self-evaluation and faculty evaluation scores were calculated and compared between males and females. Second, we clarified the change over time in mean values for students' self-evaluation and faculty evaluation scores. Finally, we compared the mean values of students' selfevaluation scores and faculty evaluation scores.

\section{Statistical Analysis}

Mann-Whitney $U$ tests were used to compare the mean values for the self-evaluation and faculty evaluation scores between males and females. Friedman and Scheffe tests were used to clarify the change over time in the mean values of students' self-evaluation and faculty evaluation scores. If a significant difference was observed, a Scheffe multiple comparison test was performed to identify where there were significant differences in each group. Wilcoxon signed-rank tests were used to compare the mean values for male and female students between students' self-evaluation and faculty evaluation scores. The level of significance (alpha) was set at 0.05 for all statistical analyses.

The sample size was calculated based on a power analysis using G*Power software version 3.1.9.2 (Heinrich Heine University, Dusseldorf, Germany). The power analysis for a Wilcoxon signed-rank test at an alpha error probability of 0.05 (effect size $=0.5$ ) showed that the actual power was 0.951 for female students and 0.980 for male students. The power analysis for the Mann-Whitney $U$ test at an alpha error probability of 0.05 (effect size $=0.8$ ) showed that the actual power was 0.980 for female students and 0.996 for male students. Finally, the power analysis for a Friedman test at an alpha error probability of 0.05 (effect size $=0.25$ ) showed that the actual power was 0.923 for sex-based differences. These results demonstrated that the sample size in each group was sufficient for statistical comparisons [29]. All statistical analyses were performed using the software Bell Curve for Excel (Social Survey Research Information Co., Ltd., Tokyo, Japan).

\section{Results}

There were no students with a two-point difference in the score between student self-evaluation and faculty evaluation on the Likert scale at the end of the unit so that no face to face individual feedback was made at the beginning of the next unit. Table 3 presents the sex-based differences in students' self-evaluation. The self-evaluation scores were significantly higher in females than in males, with this phenomenon being especially pronounced in Unit 1-3. Table 4 shows the sex-based differences in faculty evaluations. For the evaluation items concerning tidy clothes and manner as a dental student, faculty evaluation scores for female students were higher than those for male students. For the evaluation items concerning independence in role play and overall attitude, scores for female students were higher than those

Table 3 Sex-based differences in students' self-evaluation

\begin{tabular}{|c|c|c|c|c|c|c|c|c|c|c|c|c|c|c|c|}
\hline \multirow[t]{3}{*}{ Evaluation items } & \multicolumn{5}{|c|}{ Unit 1-1 } & \multicolumn{5}{|c|}{ Unit 1-2 } & \multicolumn{5}{|c|}{ Unit 1-3 } \\
\hline & \multicolumn{2}{|c|}{$\begin{array}{l}\text { Male } \\
\text { students }\end{array}$} & & \multicolumn{2}{|c|}{$\begin{array}{l}\text { Female } \\
\text { students }\end{array}$} & \multicolumn{2}{|c|}{$\begin{array}{l}\text { Male } \\
\text { students }\end{array}$} & & \multicolumn{2}{|c|}{$\begin{array}{l}\text { Female } \\
\text { students }\end{array}$} & \multicolumn{2}{|c|}{$\begin{array}{l}\text { Male } \\
\text { students }\end{array}$} & & \multicolumn{2}{|c|}{$\begin{array}{l}\text { Female } \\
\text { students }\end{array}$} \\
\hline & Mean & $\mathrm{SD}$ & & Mean & $\mathrm{SD}$ & Mean & $\mathrm{SD}$ & & Mean & $\mathrm{SD}$ & Mean & $\mathrm{SD}$ & & Mean & $\mathrm{SD}$ \\
\hline Tidy clothes as a dental student & 3.91 & 0.28 & NS & 3.98 & 0.14 & 3.86 & 0.35 & $p<0.05$ & 3.96 & 0.19 & 3.83 & 0.38 & $p<0.05$ & 3.96 & 0.19 \\
\hline Manner as a dental student & 3.83 & 0.38 & $p<0.05$ & 3.96 & 0.19 & 3.87 & 0.34 & NS & 3.94 & 0.23 & 3.81 & 0.39 & $p<0.05$ & 3.94 & 0.23 \\
\hline \multicolumn{16}{|l|}{ Role play } \\
\hline Independence & 3.77 & 0.46 & NS & 3.83 & 0.38 & 3.77 & 0.46 & $\mathrm{NS}$ & 3.81 & 0.39 & 3.67 & 0.47 & $p<0.05$ & 3.85 & 0.36 \\
\hline Cooperativeness & 3.70 & 0.49 & NS & 3.83 & 0.42 & 3.83 & 0.38 & NS & 3.87 & 0.34 & 3.76 & 0.43 & $p<0.05$ & 3.89 & 0.37 \\
\hline Sincere attitude & 3.67 & 0.47 & NS & 3.80 & 0.41 & 3.77 & 0.46 & $\mathrm{NS}$ & 3.85 & 0.36 & 3.73 & 0.45 & $p<0.05$ & 3.91 & 0.29 \\
\hline Good communication & 3.69 & 0.55 & NS & 3.80 & 0.41 & 3.79 & 0.45 & NS & 3.89 & 0.32 & 3.71 & 0.46 & $p<0.05$ & 3.87 & 0.34 \\
\hline \multicolumn{16}{|l|}{ Small-group discussion } \\
\hline Participation & 3.69 & 0.53 & NS & 3.81 & 0.39 & 3.74 & 0.50 & NS & 3.83 & 0.38 & 3.63 & 0.52 & NS & 3.72 & 0.49 \\
\hline Validity of statement & 3.64 & 0.48 & NS & 3.67 & 0.48 & 3.73 & 0.48 & NS & 3.65 & 0.48 & 3.67 & 0.47 & NS & 3.72 & 0.45 \\
\hline Attitude to hearing others' opinions & 3.79 & 0.41 & NS & 3.91 & 0.29 & 3.71 & 0.49 & $p<0.01$ & 3.94 & 0.23 & 3.77 & 0.42 & $p<0.05$ & 3.93 & 0.26 \\
\hline Good communication & 3.74 & 0.47 & NS & 3.87 & 0.34 & 3.71 & 0.49 & $p<0.05$ & 3.91 & 0.29 & 3.69 & 0.50 & NS & 3.78 & 0.46 \\
\hline Overall attitude & 16.43 & 4.83 & NS & 17.59 & 4.32 & 17.43 & 4.40 & NS & 17.78 & 4.20 & 16.86 & 4.68 & NS & 17.41 & 4.42 \\
\hline
\end{tabular}

$S D$, standard deviation; $N S$, not significant

Number of students: 70 males, 54 females 
Table 4 Sex-based differences in faculty evaluation

\begin{tabular}{|c|c|c|c|c|c|c|c|c|c|c|c|c|c|c|c|}
\hline \multirow[t]{3}{*}{ Evaluation items } & \multicolumn{5}{|c|}{ Unit 1-1 } & \multicolumn{5}{|c|}{ Unit 1-2 } & \multicolumn{5}{|c|}{ Unit 1-3 } \\
\hline & \multicolumn{2}{|c|}{$\begin{array}{l}\text { Male } \\
\text { students }\end{array}$} & & \multicolumn{2}{|c|}{$\begin{array}{l}\text { Female } \\
\text { students }\end{array}$} & \multicolumn{2}{|c|}{$\begin{array}{l}\text { Male } \\
\text { students }\end{array}$} & & \multicolumn{2}{|c|}{$\begin{array}{l}\text { Female } \\
\text { students }\end{array}$} & \multicolumn{2}{|c|}{$\begin{array}{l}\text { Male } \\
\text { students }\end{array}$} & & \multicolumn{2}{|c|}{$\begin{array}{l}\text { Female } \\
\text { students }\end{array}$} \\
\hline & Mean & SD & & Mean & SD & Mean & SD & & Mean & SD & Mean & SD & & Mean & SD \\
\hline Tidy clothes as a dental student & 3.93 & 0.26 & NS & 3.98 & 0.14 & 3.69 & 0.50 & NS & 3.72 & 0.45 & 3.57 & 0.50 & $p<0.01$ & 3.78 & 0.50 \\
\hline Manner as a dental student & 3.91 & 0.33 & NS & 3.98 & 0.14 & 3.51 & 0.56 & NS & 3.69 & 0.47 & 3.49 & 0.56 & $p<0.01$ & 3.80 & 0.41 \\
\hline \multicolumn{16}{|l|}{ Role play } \\
\hline Independence & 3.44 & 0.50 & $p<0.05$ & 3.65 & 0.48 & 3.15 & 0.50 & $p<0.01$ & 3.80 & 0.41 & 3.44 & 0.53 & NS & 3.44 & 0.54 \\
\hline Cooperativeness & 3.61 & 0.55 & NS & 3.80 & 0.41 & 3.59 & 0.50 & NS & 3.74 & 0.44 & 3.50 & 0.53 & NS & 3.69 & 0.47 \\
\hline Sincere attitude & 3.51 & 0.63 & NS & 3.69 & 0.47 & 3.46 & 0.56 & NS & 3.61 & 0.49 & 3.30 & 0.71 & NS & 3.44 & 0.66 \\
\hline Good communication & 3.47 & 0.53 & $p<0.05$ & 3.28 & 0.45 & 3.59 & 0.50 & NS & 3.50 & 0.51 & 3.49 & 0.53 & NS & 3.52 & 0.54 \\
\hline \multicolumn{16}{|l|}{ Small-group discussion } \\
\hline Participation & 3.49 & 0.53 & NS & 3.59 & 0.50 & 3.66 & 0.51 & NS & 3.74 & 0.44 & 3.36 & 0.57 & NS & 3.33 & 0.58 \\
\hline Validity of statement & 3.37 & 0.49 & NS & 3.44 & 0.50 & 3.33 & 0.56 & $p<0.01$ & 3.61 & 0.49 & 3.39 & 0.60 & NS & 3.43 & 0.57 \\
\hline Attitude to hearing others' opinions & 3.56 & 0.53 & NS & 3.63 & 0.49 & 3.57 & 0.53 & NS & 3.65 & 0.48 & 3.54 & 0.53 & NS & 3.63 & 0.49 \\
\hline Good communication & 3.49 & 0.50 & NS & 3.50 & 0.51 & 3.53 & 0.50 & $p<0.05$ & 3.70 & 0.46 & 3.54 & 0.50 & NS & 3.44 & 0.50 \\
\hline Overall attitude & 14.36 & 5.10 & $p<0.01$ & 17.04 & 4.61 & 14.50 & 5.12 & $p<0.01$ & 17.78 & 4.20 & 15.50 & 5.12 & NS & 16.67 & 4.76 \\
\hline
\end{tabular}

$S D$, standard deviation; $N S$, not significant

Number of students: 70 males, 54 females

Number of faculties: 3 males, 3 females

for males in Units 1-1 and 1-2, whereas no significant differences were observed in Unit 1-3.

The self-evaluation for male and female students is shown in Table 5. For female students, a significant difference was observed between Units 1-2 and 1-3 for the item good communication in small-group discussion. The faculty evaluation for students is shown in Table 6. For the evaluation items of tidy clothes and manner as a dental student, significant differences were observed between Units 1-1 and 1-2 between males and females. Significant differences were also observed between Units 1-2 and 1-3 between males and females for participation in smallgroup discussion. For independence in role play and good communication in small-group discussion, there were significant differences in female students between Units 1-2 and 1-3. For the evaluation item concerning good communication in role play, a significant difference was observed in female students between Units 1-1 and 1-3.

Table 7 presents the differences between male students' selfevaluation and faculty evaluations. The evaluation items with significant differences between male students' self-evaluation and faculty evaluation increased from Unit 1-1 to Unit 1-3. For Unit 1-3, significant differences were observed in nine of the 11 evaluation items. Table 8 shows the differences between female students' self-evaluation and faculty evaluations. The evaluation items with a significant difference between female students' selfevaluation and faculty evaluations increased from Unit 1-1 to Unit 1-3. For Unit 1-3, significant differences were observed for 10 of the 11 evaluation items.

\section{Discussion}

In this study, female students tended to rate significantly higher self-assessment scores than male students. This tendency became stronger as the practical training progressed. Wiener et al. [15] also reported that female students' selfevaluations were higher than those of male students. Our result was consistent with the reports that analyzed dental students [15] and medical students [14] in the USA. Our result was also consistent with the other study that analyzed nonmedical students in Europe [28]. Our findings and these consistencies indicated that sex-based difference in the student's self-evaluation is not affected by health promotion educational programs with different education systems and curricula. Colbert-Getz et al. [11] suggested that these scores were influenced by anxiety and confidence. Female students may perform better relative to male students because female students study more and are more prepared [30]. This suggests that female students in this study had more self-confidence and therefore tended to rate significantly higher selfassessment scores than male students. Female students may do better with several interpersonal aspects of medical care as Gruppen et al. reported [14]. On the other hand, VivekanandaSchmidt et al. [26] and some other researchers advocated in their article that female students tend to underestimate themselves compared with male students on self-evaluation [12, 27]. Further research would be needed to clarify the relationship between sex and self-evaluation scores. Japanese dental 
Table 5 Students' self-evaluation

\begin{tabular}{|c|c|c|c|c|c|c|c|c|c|c|c|c|}
\hline \multirow[t]{2}{*}{ Evaluation items } & \multirow[t]{2}{*}{ Gender } & \multicolumn{2}{|c|}{ Unit 1-1 } & \multicolumn{2}{|c|}{ Unit 1-2 } & \multicolumn{2}{|c|}{ Unit 1-3 } & \multirow[t]{2}{*}{ Friedman test } & \multicolumn{4}{|c|}{ Comparison between measurement times } \\
\hline & & Mean & SD & Mean & SD & Mean & $\mathrm{SD}$ & & Scheffe & $1-1$ vs. $1-2$ & $1-1$ vs. $1-3$ & $1-2$ vs. $1-3$ \\
\hline \multirow[t]{2}{*}{ Tidy clothes as a dental student } & Males & 3.91 & 0.28 & 3.86 & 0.35 & 3.83 & 0.38 & NS & & & & \\
\hline & Females & 3.98 & 0.14 & 3.96 & 0.19 & 3.96 & 0.19 & NS & & & & \\
\hline \multirow[t]{2}{*}{ Manner as a dental student } & Males & 3.83 & 0.38 & 3.87 & 0.34 & 3.81 & 0.39 & NS & & & & \\
\hline & Females & 3.96 & 0.19 & 3.94 & 0.32 & 3.94 & 0.23 & NS & & & & \\
\hline \multicolumn{13}{|l|}{ Role play } \\
\hline \multirow[t]{2}{*}{ Independence } & Males & 3.77 & 0.46 & 3.77 & 0.46 & 3.67 & 0.47 & NS & & & & \\
\hline & Females & 3.83 & 0.38 & 3.82 & 0.39 & 3.85 & 0.36 & NS & & & & \\
\hline \multirow[t]{2}{*}{ Cooperativeness } & Males & 3.70 & 0.49 & 3.83 & 0.38 & 3.76 & 0.43 & NS & & & & \\
\hline & Females & 3.83 & 0.42 & 3.87 & 0.34 & 3.89 & 0.37 & NS & & & & \\
\hline \multirow[t]{2}{*}{ Sincere attitude } & Males & 3.67 & 0.47 & 3.77 & 0.46 & 3.73 & 0.45 & NS & & & & \\
\hline & Females & 3.80 & 0.41 & 3.85 & 0.36 & 3.91 & 0.29 & NS & & & & \\
\hline \multirow[t]{2}{*}{ Good communication } & Males & 3.69 & 0.55 & 3.79 & 0.45 & 3.71 & 0.46 & NS & & & & \\
\hline & Females & 3.80 & 0.41 & 3.89 & 0.32 & 3.87 & 0.34 & NS & & & & \\
\hline \multicolumn{13}{|l|}{ Small-group discussion } \\
\hline \multirow[t]{2}{*}{ Participation } & Males & 3.69 & 0.53 & 3.74 & 0.50 & 3.63 & 0.52 & NS & & & & \\
\hline & Females & 3.82 & 0.39 & 3.83 & 0.38 & 3.72 & 0.49 & NS & & & & \\
\hline \multirow[t]{2}{*}{ Validity of statement } & Males & 3.64 & 0.48 & 3.74 & 0.48 & 3.67 & 0.47 & NS & & & & \\
\hline & Females & 3.67 & 0.48 & 3.65 & 0.48 & 3.72 & 0.45 & NS & & & & \\
\hline \multirow[t]{2}{*}{ Attitude to hearing others' opinions } & Males & 3.79 & 0.41 & 3.71 & 0.49 & 3.77 & 0.42 & NS & & & & \\
\hline & Females & 3.91 & 0.29 & 3.94 & 0.23 & 3.93 & 0.26 & NS & & & & \\
\hline \multirow[t]{2}{*}{ Good communication } & Males & 3.74 & 0.47 & 3.71 & 0.49 & 3.69 & 0.50 & NS & & & & \\
\hline & Females & 3.87 & 0.34 & 3.91 & 0.29 & 3.78 & 0.46 & $p<0.05$ & & NS & NS & $p<0.05$ \\
\hline \multirow[t]{2}{*}{ Overall attitude } & Males & 16.43 & 4.83 & 17.43 & 4.40 & 16.86 & 4.68 & NS & & & & \\
\hline & Females & 17.59 & 4.32 & 17.78 & 4.20 & 17.41 & 4.42 & NS & & & & \\
\hline
\end{tabular}

$S D$, standard deviation; $N S$, not significant

Number of students: 70 males, 54 females

students tended to prefer passive learning because of their selfrestraint and reticence [31]. Traditionally, dentistry in Japan was a male-dominated profession and the percentage of female dental students was below 50\%. In recent years, the number of female students is increasing in Japanese dental schools. Regarding the cultural and generational difference in gender roles, it may be that the learning preference and behavior of Japanese dental students may change as women assume a more assertive role in dentistry in Japan [32].

The results of the present study showed there were significant differences in evaluation scores between students and faculty in Unit 1-3 for nine of the 11 evaluation items for male students and 10 of the 11 items for female students. The results also showed that faculty evaluation scores decreased from Unit 1-1 to Unit 1-3. Emam et al. [17] suggested that overestimation in student's self-evaluation may be attributed to those students having assessed their performance based on their memory and self-confidence that exceeded their expectations. The level of faculty expectations became higher from Unit 1-1 to Unit 1-3; however, students were satisfied with their performance based on their sense of achievement. Differences between student self-evaluation and faculty evaluation might be attributed to the students' lesser understanding of the criteria used and not to the performance as such. In the present study, we employed just an evaluation sheet and a written criterion for evaluation, and we did not employ the rubric. There were no students with a two-point difference in the score between student self-evaluation and faculty evaluation on the Likert scale at the end of the unit so that no face to face individual feedback was made at the beginning of the next unit. Thus, it may be considered that the students were developing the assessment skills with group feedback and faculty feedback on the validity of their assessment. The rubric might support student's self-evaluation as examples, to explain the various levels of attainment. The rubric implies both student and faculty what is important and thereby give clarity and explicitness to the assessment [33-35]. It may be considered that the use of rubric has the potential of promoting learning and/or improving instruction, at least as perceived by the students and faculties using them. How rubrics support 


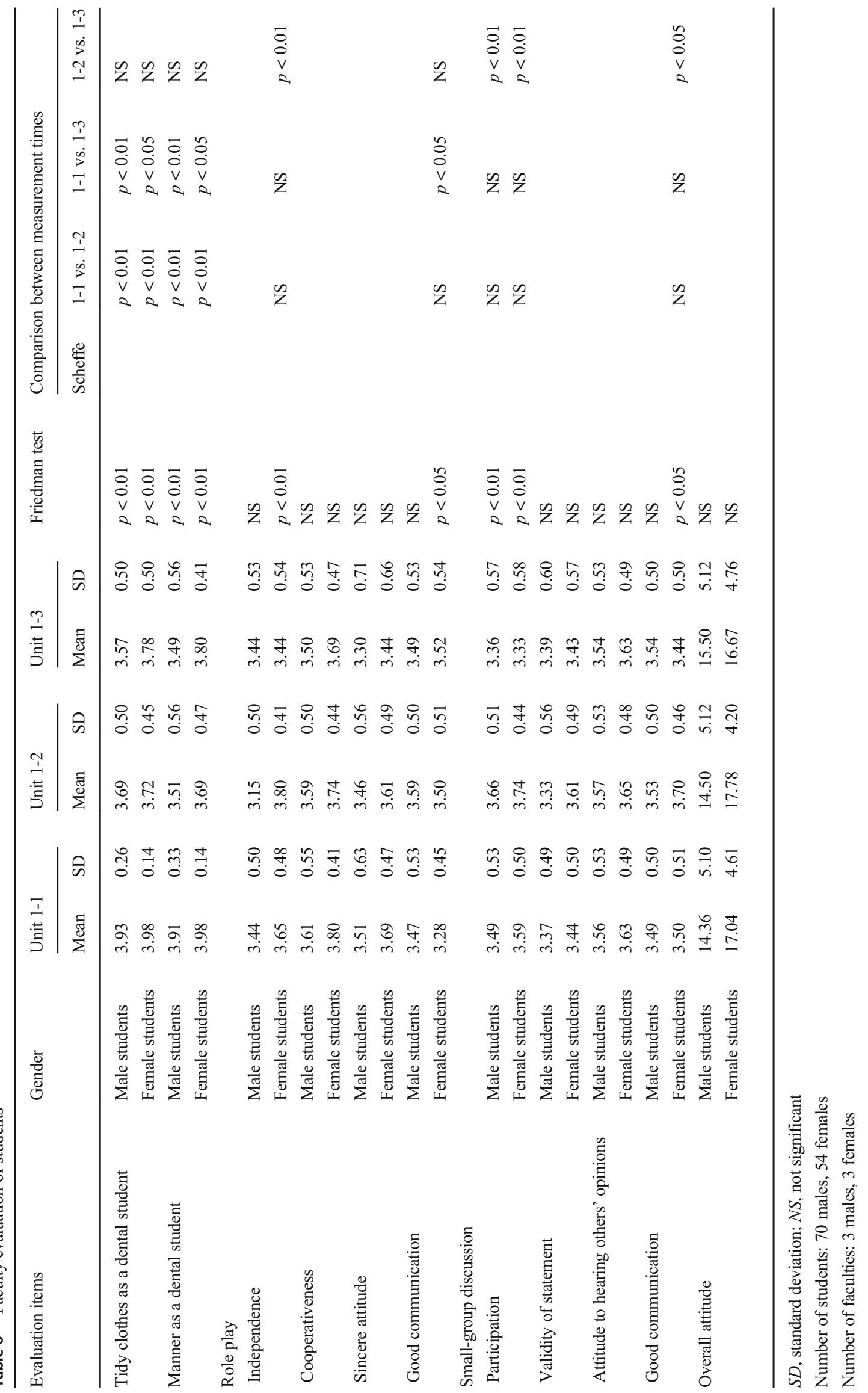




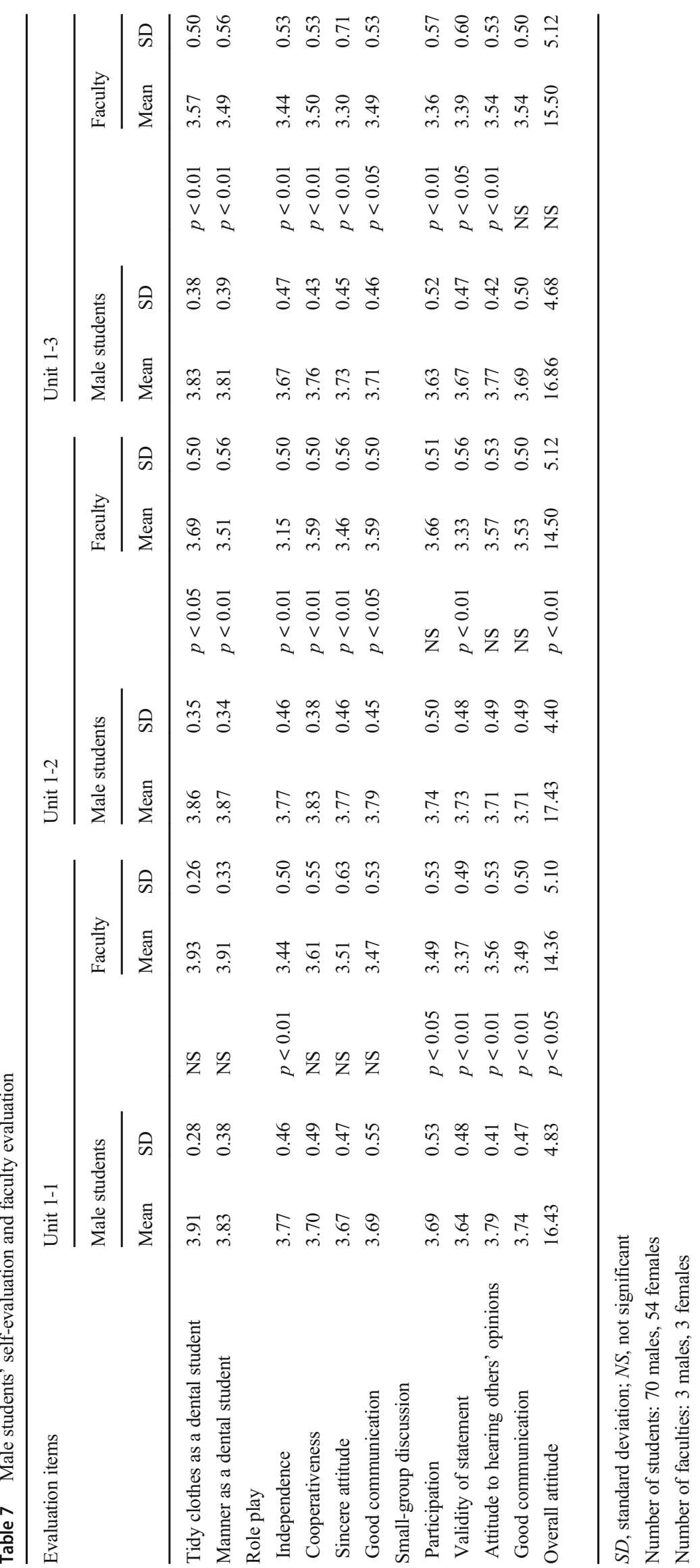




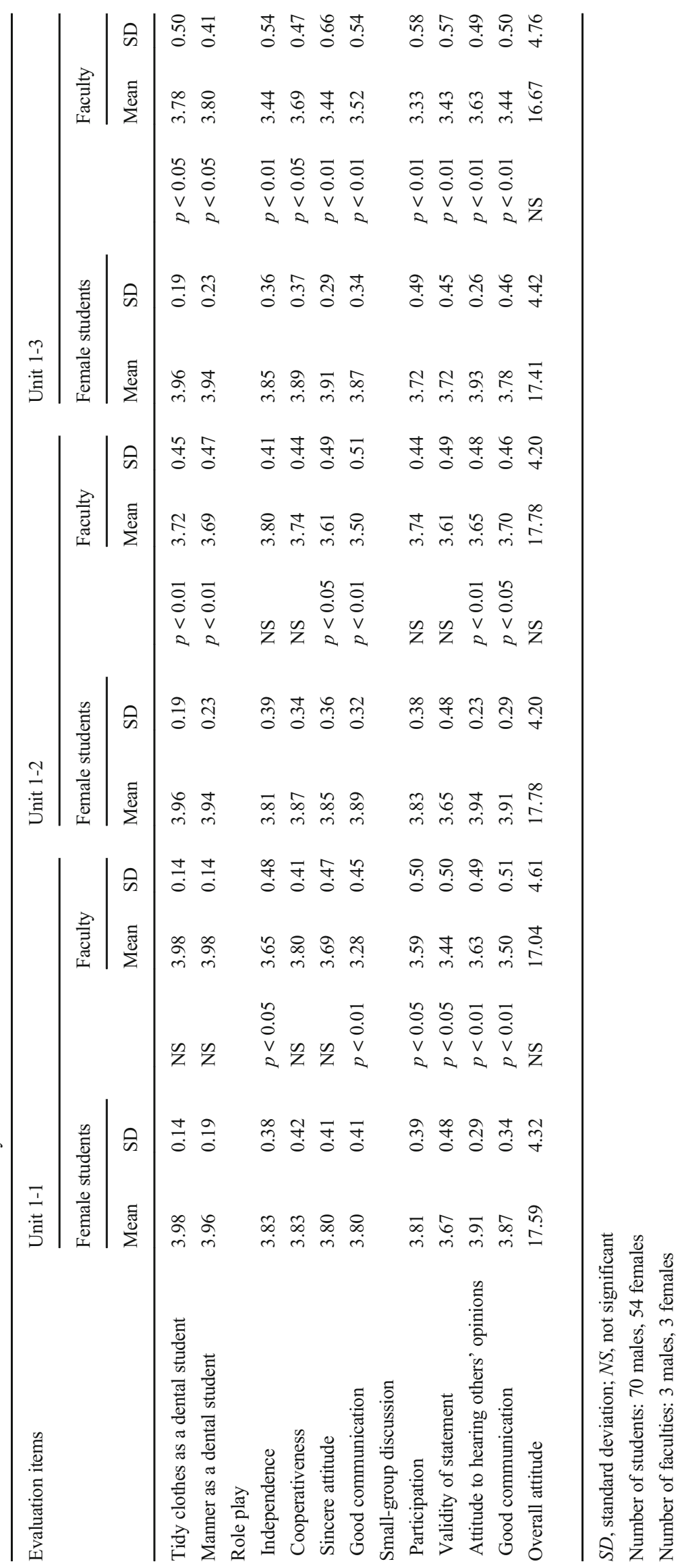


learning and instruction is by making expectations and criteria explicit, which also facilitates feedback and self-evaluation [36]. In further research after employing the rubric in the "communication skills in clinical dentistry practical course," we would like to ascertain the effect of that to students' selfevaluation and faculty evaluation.

Based on Bandura's theory [37], Hadid [10] reported that self-efficacy affects self-evaluation, which implies that students who believe they can perform a certain task usually do not experience negative thoughts about their ability to perform that task successfully. Self-evaluation-based self-assessment is an important skill for dentists in daily clinical practice to provide effective oral care [38]. The ability to accomplish selfassessment requires training and practice and helps the professional to understand their strengths and weaknesses [39]. The validity of self-assessment is important for health professionals looking to self-directed life-long learning as a source of continuing professional vitality [40].

The present study was limited in that the two cohorts were restricted to students at one dental university. Although this study was conducted over two academic years, our results represent a small sample of students. Due to the limitation of the sample size of involved students and numbers of faculty who participate in the "communication skills in clinical dentistry practical course," this study was not able to ascertain whether the gender of the faculty member influenced the assessment of students of the other gender. In this study, the faculty evaluation of the students was employed, not the control group of the students. McKenzie et al. [18] set the intervention group and no intervention/control group in their research. In their study, the intervention group was a class of 2016 and no intervention/control group was a class of another year (2015). On the other hand, the research papers without control group settings were published $[2,10$, $15,17,35]$. Further study would be needed for the comparison of students' self-evaluation skills between the intervention group and no intervention/control group to analyze the Japanese students' behavior. So, we analyzed the student classes of 2017 and 2018 in the present study for the control group of further research. Wagner et al. [7] noted that the self-assessment process should be validated; students should receive adequate training on how to use these skills and be enabled to practice self-assessment frequently. Additionally, students' self-assessment skills were still developing because they were fourth-year students in a 6-year dental school curriculum. All of the tutors who participated in the "communication skills in clinical dentistry practical training course" belonged to the clinical department of our university, and they treat patients in the university hospital. Thus, it is possible that the tutors can check later year students and young dentists exhibit the intended behaviors or not. During the internship of dental students, it may be considered that the students' behaviors reinforced in their clinical experiences. In further research, we would like to clarify this point as well. Despite these limitations, the results of this study indicated that students' self-assessment offered the possibility of enhancing their ability for self-directed dentistry learning, and also offered insight as to how faculty can effectively educate dental students. Although further studies are required, we believe that dental educators need to assume the responsibility of helping students to develop skills in decision-making, communication, professionalism, and reflection for lifelong learning [20].

The null hypothesis of the present study that there was no difference between male and female students' self-evaluation scores was rejected. Also, the null hypothesis that there was no difference between student's self-evaluation and faculty evaluation was rejected. Dental educators should support students to increase their levels of self-efficacy to enhance their self-evaluation skills. Enhancing students' self-evaluation skills may lead to improvements in student's learning skills and learning approaches for better academic performance.

Acknowledgments We thank Professor emeritus Yukio Miyagawa, The Nippon Dental University, School of Life Dentistry at Niigata, for his assistance in the statistical analyses. We also thank Audrey Holmes, MA, from Edanz Group (www.edanzediting.com/ac) for editing a draft of this manuscript.

\section{Compliance with Ethical Standards}

All procedures performed in this study involving human participants were in accordance with the ethical standards of the institutional and/or national research committee, and with the 1964 Helsinki Declaration and its later amendments or comparable ethical standards.

Conflict of Interest The authors declare that they have no conflicts of interest.

Ethical Approval Approval for this study was granted by the Research Ethics Committee of The Nippon Dental University School of Life Dentistry at Niigata (Approval No. ECNG-E-3).

Informed Consent Informed consent was obtained from all individual participants included in this study. All students and faculty who participated in this study signaled their agreement to participate on a consent form. Participation was voluntary, and only data from consenting students were used in the analyses.

Open Access This article is licensed under a Creative Commons Attribution 4.0 International License, which permits use, sharing, adaptation, distribution and reproduction in any medium or format, as long as you give appropriate credit to the original author(s) and the source, provide a link to the Creative Commons licence, and indicate if changes were made. The images or other third party material in this article are included in the article's Creative Commons licence, unless indicated otherwise in a credit line to the material. If material is not included in the article's Creative Commons licence and your intended use is not permitted by statutory regulation or exceeds the permitted use, you will need to obtain permission directly from the copyright holder. To view a copy of this licence, visit http://creativecommons.org/licenses/by/4.0/. 


\section{References}

1. Dy-Boarman EA, Diehl B, Mobley-Bukstein W, Bottenberg MM, Bryant GA, Sauer H. Comparison of faculty and student selfassessment scores of aseptic technique skills and the impact of video review on self-awareness for second-year pharmacy students. Curr Pharmac Teach Learn. 2018;10:201-5.

2. Pawluk SA, Zolezzi M, Rainke D. Comparing student selfassessments of global communication with trained faculty and standardized patient assessments. Curr Pharmac Teach Learn. 2018;10: 779-84.

3. Poirier TI, Pailden J, Jhala R, Ronald K, Wilhelm M, Fan J. Student self-assessment and faculty assessment of performance in an interprofessional error disclosure simulation training program. Am $\mathbf{J}$ Pharm Educ. 2017;81:Article 54.

4. Widder-Prewett R, Draime JA, Cameron G, Anderson D, Pinkerton M, Aleda MH. Impact of student vs faculty facilitators on motivational interviewing student outcomes. Am J Pharm Educ. 2017;81: Article 107.

5. Trujillo JM, Saseen JJ, Linnebur SA, Borgelt LM, Hemstreet BA, Fish DN. Impact of student- versus instructor-directed case discussions on student performance in a pharmacotherapy capstone course. Am J Pharm Educ. 2014;78:Article 56.

6. Lundquist LM, Shogbon AO, Momary KM, Rogers HK. A Comparison of students' self-assessments with faculty evaluations of their communication skills. Am J Pharm Educ. 2013;77:Article 72 .

7. Wagner ML, Suh DC, Cruz S. Peer- and self-grading compared to faculty grading. Am J Pharm Educ. 2011;75:Article 130.

8. Mort JR, Hansen DJ. First-year pharmacy students' self-assessment of communication skills and the impact of video review. Am J Pharm Educ. 2010;74:Article 78.

9. Tanoue N, Korovin LN, Carton M, Galvani CA, Ghaderi I. Faculty feedback versus residents' self-assessment of operative performance: different but complementary. Am J Surg. 2018;215:28892.

10. Hadid S. Factors influencing nursing student self-assessment in relation to instructor assessment. J Nurs Educ. 2017;56:70-6.

11. Colbert-Getz J, Flishman C, Jung J. How do gender and anxiety affect students' self-assessment and actual performance on a highstakes clinical skills examination? Acad Med. 2013;88:44-8.

12. Lind DS, Rekkas S, Bui V, Lam T, Beierle E. Copeland 3rd EM. Competency based student self-assessment on a surgery rotation. J Surg Res. 2002;105:31-4.

13. Coutts L, Rogers J. Predictors of student self-assessment accuracy during a clinical performance exam: comparisons between overestimators and under-estimators of SP evaluated performance. Acad Med. 1999;74:S128-30.

14. Gruppen LD, Garcia J, Grum CM, Fitzgerald JT, White CA, Dicken L, et al. Medical students' self-assessment accuracy in communication skills. Acad Med. 1997;72:S57-9.

15. Wiener R, Waters C, Doris J, Mcneil DW. Comparison of dental students' self-evaluation and faculty evaluation of communication skills during a standardized patient exercise. J Dent Educ. 2018;82: 1043-50.

16. Habib SR, Sherfudhin H. Students' self-assessment: a learning tool and its comparison with the faculty assessments. J Contemp Dent Prac. 2015;16:48-53.

17. Emam HA, Jatana CA, Wade S, Hamamoto D. Dental student selfassessment of a medical history competency developed by oral and maxillofacial surgery faculty. Eur J Dent Educ. 2016;22:9-14.

18. McKenzie CT, Tilashalski KR, Peterson DT, White ML. Effectiveness of standardized patient simulations in teaching clinical communication skills to dental students. J Dent Educ. 2017;81:1179-83.

19. Kim AH, Chutinan S, Park SE. Assessment skills of dental students as peer evaluators. J Dent Educ. 2015;79:653-7.

20. Quick KK. The role of self- and peer assessment in dental students' reflective practice using standardized patient encounters. J Dent Educ. 2016;80:924-9.

21. Bitter K, Rüttermann S, Lippmann M, Hahn P, Giesler M. Selfassessment of competencies in dental education in Germany- a multicentred survey. Euro J Dent Educ. 2015;20:229-36.

22. McMillan J, Hearn J. Student self-assessment. The key to stronger student motivation and higher achievement. Educ Horizons. 2009;87:40-9.

23. Haist SA, Wilson JF, Elam CL, Blue AV, Fosson SE. The effect of gender and age on medical school performance: an important interaction. Adv Health Sci Educ Theory Pract. 2000;5:197-205.

24. Antonelli MA. Accuracy of second-year medical students' selfassessment of clinical skills. Acad Med. 1997;72:S63-5.

25. Kaiser S, Bauer JJ. Checklist self-evaluation in a standardized patient exercise. Am J Surg. 1995; 169:418-20.

26. Vivekananda-Schmidt P, Lewis M, Hassell AB, Coady D, Walker D, Kay L, et al. Validation of MSAT: an instrument to measure medical students' self-assessed confidence in musculoskeletal examination skills. Med Educ. 2007;41:402-10.

27. Rees C. Self-assessment scores and gender. Med Educ. 2003;37: 572-3.

28. Tariq V, Durrani N. Factors influencing undergraduates' selfevaluation of numerical competence. Int J Math Educ Sci Technol. 2012;43:337-56.

29. Faul F, Erdfelder E, Lang AG, Buchner A. G*Power 3: a flexible statistical power analysis program for the social, behavioral, and biomedical sciences. Behav Res Methods. 2007;39:175-91.

30. Strickler LJ, Rock DA, Burton NW. Sex differences in predictions of college grades from scholastic aptitude test scores. J Educ Psychol. 1993;85:710-8.

31. Yan X, Zhang X, Jinno Y, Tachibana K, Gao J, Koyano K, et al. Comparison of attitudes towards dental education among dental students in Japan and China. Int Dent J. 2014;64:76-82.

32. Sugiura G, Shinada K, Kawaguchi Y. Psychological well-being and perceptions of stress amongst Japanese dental students. Eur J Dent Educ. 2005;9:17-25.

33. Bissell AN, Lemons PR. A new method for assessing critical thinking in the classroom. Biomed Sci. 2006;56:66-72.

34. Schamber JF, Mahoney SL. Assessing and improving the quality of group critical thinking exhibited in the final projects of collaborative learning groups. J Gen Educ. 2006;55:103-37.

35. Shaw J. Demystifying the evaluation process for parents: rubrics for marking student research projects. Teach Libr. 2004;32:16-9.

36. Jonsson A, Svingby G. The use of scoring rubrics: reliability, validity and educational consequences. Educ Res Rev. 2007;2:130 44.

37. Bandura A. Self-efficacy: toward a unifying theory of behavioral change. Psychol Rev. 1997;84:191-215.

38. Mattheos N, Natestad A, Falk-Nilsson E, Attström R. The interactive examination: assessing students' self-assessment ability. Med Educ. 2004;38:378-89.

39. Cho GC, Chee WW, Tan DT. Dental students' ability to evaluate themselves in fixed prosthodontics. J Dent Educ. 2010;74:1237-42.

40. Gordon MJ. A review of the validity and accuracy of selfassessments in health professions training. Acad Med. 1991;66: $762-9$.

Publisher's Note Springer Nature remains neutral with regard to jurisdictional claims in published maps and institutional affiliations. 